\title{
Marketing Footwear: A Case Study from Greece
}

\author{
Evangelia K. Blery (Corresponding Author) \\ TEI of Piraeus, Petrou Ralli \& Thivon 250, Aigaleo 12244, Greece
}

Tel: 30-210-600-5950,30-694-495-5733. E-mail: eviblery@gmail.com

George Kakokefalos

TEI Piraeus, Petrou Ralli \& Thivon 250, Aigaleo 12244, Greece

E-mail: kakokefalosgeorge@gmail.com

Received: January 8, 2014 Accepted: January 15, 2013 Published: February 7, 2014

doi:10.5296/rbm.v1i1.5080 URL: http://dx.doi.org/10.5296/rbm.v1i1.5080

\begin{abstract}
The purpose of this paper is to examine the issues related to the marketing practices implemented by the Greek company, Leon Tamaris \& Co, producing and importing footwear. Thus, the company's target market and competition are examined, a PEST and a SWOT analysis are performed and the marketing mix is presented.

To gain an initial understanding of the marketing practices employed by the company, the case study method was employed, since its fundamental characteristic is the "focus on a particular setting or event".

The findings showed that the company, despite the economic crisis that has hit Greece and the strong competition has encouraging results, its market share remains stable and an increase in its sales is expected. The company's products are of high quality and prices are good, thus it has a good fame in the market as a company offering 'value for money'. It has its own retail network and well trained employees and is trying to select the right employees to best fill all the positions. The company conducts market researches to identify customers' needs and assess their satisfaction.

This paper can add to the present pool of knowledge in the footwear sector, since it is one of the very few that have provided an important insight in the marketing practices in the Greek footwear sector. The results of the study support the findings of other studies mentioned in the literature and they can be of definite interest and potential value to managers in this sector.
\end{abstract}

Keywords: marketing, footwear, case study, PEST analysis, SWOT analysis, marketing mix 


\section{Introduction}

Leon Tamaris \& Co is a company producing and importing footwear, which is operating in Greece since 2000. The company produces footwear for women under the trade mark 'Tamaris' and is also importing shoes from Germany.

The aim of this study is to examine the issues related to the production of footwear and the marketing practices implemented by Leon Tamaris \& Co, a significant player in the Greek footwear market. Thus, the products of the company, its target market and competition are analyzed, a SWOT analysis is performed and the marketing mix is presented. The marketing practices implemented by the company will then be assessed on the basis of those employed by other companies in the international market.

\section{Literature Review}

\subsection{The Footwear Market}

The global footwear market at retail was $\$ 192.3$ billion in 2008. For the 2004-2008 period, the global footwear market grew at a compound annual growth rate of six percent (Packaged Facts, 2009). Major players in the global marketplace include Adidas AG, Bata Shoe Organization, Brown Shoe Company, Deckers Outdoor Corporation, ECCO Sko A/S, Gucci Group, Kenneth Cole Productions, LaCrosse Footwear, Nike, Nine West Group, Puma AG, R.G. Barry Corporation, Vans, Weyco Group, Wolverine World Wide, among others.

The EU is the largest market for footwear, being ahead of the USA, representing one third of the global market value. In 2008, EU consumption was $€ 49$ billion (2.1 billion pairs) with an average per capita expenditure of $100 €$ or 4.2 pairs. The market was dominated by five countries, which accounted for $71 \%$ of total EU consumption. These markets were Germany (17.4\%), France (17.0\%), the UK (16.1\%), Italy (12.6\%) and Spain (8.3\%) (CBI, 2010a).

Since 2004, sales in most EU countries increased quite strongly up to 2007, before they were affected by the global economic downturn in 2008. The best-performing sectors were casual footwear (boots, ballerinas), sports footwear (sneakers) and evening footwear. In 2008, footwear sales fell in most EU countries as consumers tended to cut expenditure on footwear, or increasingly were looking for footwear at the lowest possible prices.

The major stimulants are the changes in fashion, new footwear styles, including recycled footwear and ethical footwear, as well as technological innovations in comfortable footwear (GIA, 2012).

The EU has traditionally been an important supplier of high quality footwear to the world market. However, production of high volume items has been outsourced to mainly Asia. Now 6 out of 10 shoes in the world are produced in China.

In 2008, there were around 13,500 companies with 198,000 employees and about 52,000 footwear retail outlets in the EU. Most of these were family businesses employing less than 20 people. Leather footwear accounts for $72 \%$ of the EU production. Italy accounted for almost half of total EU production, being known for its artisanship and for its high 
fashionable and innovative footwear. Other important EU Producers are Germany, Spain, Romania, Portugal, France, Austria and Poland. EU footwear producers are now outsourcing in nearby countries that are cheaper, flexible and can supply small quantities with shorter lead times (CBI, 2010b).

EU producers focus more on exports of footwear to emerging markets in China, Brazil, India, Russia and the Middle East and join forces to compete on a global level. EU exports increased between 2004 and 2008 by an annual average of $2.7 \%$ in value from $€ 20.0$ to $€$ 22.3 billion and $5.3 \%$ in volume from 992 to 1.2 billion pairs. Italy is the largest exporter, accounting for $32 \%$ of the value of all EU exports (17\% by volume).

The EU is the world's largest importer of footwear, importing $25 \%$ more than the volume of USA imports. In 2008, EU footwear imports represented 3.1 billion pairs, valued at $€ 26.6$ billion.

. The EU footwear production industry concentrates on providing added value in better designs, quality materials, comfort and in other innovations e.g. vegetable tanned shoes to meet the strict environmental rules and to compete with China, Vietnam and India.

In most EU countries, footwear increasingly has become a statement among working women. A good design, fashion and more walking comfort are driving the market.

The Greek footwear market in 2008 valued at $€ 1.2$ billion in terms of retail sales. Production volume was 5 million pairs of shoes and represented a sales turnover of $€ 121$ million, an average annual decrease of $4.8 \%$ compared to $€ 147$ million in 2004. Greece was the ninth largest EU market, behind Belgium but ahead of Austria and Sweden (CBI, 2010b).

Some years ago the Greek footwear industry was a significant industry, but lack of investment in new technologies restrained a further development. The Greek footwear industry is small compared to other EU countries and produces a wide range of different products aimed at different market segments. Much production is focused on the local market. In 2007, there were 93 companies, employing 2,137 people in Greece. Although there are some large companies that are also involved in retailing, the majority of these companies are single person or family businesses (CBI, 2010b).

By volume, the Greeks bought 37 million pairs in 2008, which meant 3.9 pairs per capita, spending $€ 118$ per year, being in value above the EU average of $€ 100$ per capita (4.2 pairs).

In 2008, the market has contracted as Greece was hit hard by the international recession and this has meant a cut in expenditure on non-essential items such as clothing and footwear. Thus, the total turnover of the footwear sector in the period from August 2010 to July 2011 showed a decrease of $27.6 \%$ in comparison with the same period in the previous year (2010/2009) (Kathimerini, 2012).

Brand awareness is strong in Greece and is often connected to social status. Women spend almost twice as much on footwear as men. Women's footwear in 2007 had $61 \%$ of the Greek footwear market and in $200871.8 \%$, so much marketing expenditure in the footwear market is directed at women. Children's footwear had the $16 \%$ and men's footwear had the smallest 
percentage 12.3\% (Vima, 2009). Children's footwear saw slower growth due to falling birth rate.

Footwear demand is characterized by seasonality, with purchases made mainly during Christmas and Easter holidays as well as during sales periods. According to a research conducted by the Centre of Consumer Protection in 2008, Greek working people spend more than the $12 \%$ of their monthly salary for buying shoes during the Christmas holidays. However, as income levels now have been reduced that has meant that many Greeks currently spend less than this (CBI, 2010b).

In 2008 , around $60 \%$ of the market volume was casual footwear; $20 \%$ sports footwear; $13 \%$ formal shoes and 7\% evening shoes. Imported footwear, including sports footwear and sneakers, mainly from Asia was boosted by heavy promotions in the clothing chains and supermarkets (CBI, 2010b).

Prices of footwear in Greece are just below the EU average, but there exists a large segment at the bottom of the market for low priced goods and a premium segment based on increased sales of high-priced international brands.

\subsection{Marketing Practices in the Footwear Market}

Most footwear is supplied in most EU countries through the specialized distribution route, which is from manufacturer to importer/wholesaler to retailer. Footwear retailing has become more diversified. Consumers can nowadays buy footwear in many different ways, ranging from a footwear or clothing shop to a sports shop to a hypermarket, factory outlet or by the Internet. Most companies in the sector of footwear have developed their own retail networks, controlling in this way the promotion of their products in the market. Hyperstores have a variety of shoes of different companies and it is less expensive to sell footwear through hyperstores than to open a new retail outlet. Hyperstores attract a greater number of consumers than the retail stores (CBI, 2010b).

A footwear company should design pricing by taking into consideration the prices of its competitors so as to be competitive. In addition, it should offer a wider selection of products than its competitors. Location, targeted advertising in the newspaper and fashion magazines and strategic alliances will serve as the foundation of advertising and promotion effort (Mplans, 2012)

Today footwear industry has begun to see the need to adopt eco-friendly practices. Shoe manufacturers are improving their production methods to reduce the size of the carbon footprint they leave behind. However, recognizing that green assembly is not enough, the industry has incorporated recycled and biodegradable materials into their production of eco-friendly footwear. Shoe manufacturers can actually save money by going green. Production practices such as wind energy, solar energy, waste-to-energy conversion, energy conserving machinery, are becoming more and more popular in manufacturing because of their ability to cut costs. In addition, the use of green textiles such as recycled wool and polyester, polyethylene terephthalate (PET), organic cotton etc and post-consumer materials within eco-friendly footwear manufacturing has already made a significant impact on 
reducing the negative effects of the industry on the Earth. Other Eco-Friendly Practices include streamlining processes, green packaging, and overstock donations. Eco-friendly footwear companies are applying the green initiative to all aspects of their business by implementing sustainable corporate policies and green packaging methods. Boxes are being made out of recycled materials and catalogs are being printed on post-consumer paper with soy ink. More and more companies are choosing to eliminate waste by donating overstock and outdated shoes to organizations round the world (Pelikan, 2012).

One of the major players in the international footwear market is Nike. The company is conducting marketing research on a continual basis to gain a better understanding on what customers would like to see in the market. Nike implemented a successful marketing and reaches millions of consumers through large-scale marketing campaigns. The company conducted aggressive advertising campaigns, celebrity endorsements, quality products to enhance the brand and sponsored athletic events.

Nike's distinctive competency lies in the area of marketing, particularity in the area of consumer brand awareness and brand power. The company protected its market share among female consumers within the industry by targeting some promotions to female consumers. Nike's sponsorship of the 1999 Women's World Cup Soccer Tournament was a great example of how Nike is appealing to female athletes.

Nike has had much success as a result of collaborating with other companies within the sports and fitness industry. The company expanded its activities in clothing and accessories and has taken the lead in e-commerce by being the first to market with its e-commerce web-site in April 1999 by offering 65 styles of shoes to the U.S. market for purchase. Nike increased its e-commerce presence by launching NIKEiD in November 1999. NIKEiD enables online consumers to design key elements of the shoes they purchase. In general, Nike's products are considered to be of higher quality and as a result have higher prices relative to its competitors. However, the prices are realistic given the nature of its products. The company established labor policies and education programs. The locations are geographically dispersed and the production facilities are located close to raw materials and cheap labor sources. They have been strategically placed in their locations for just this purpose.

Ethics is very important and accusations of unethical behavior, injure companies' image and as a result, product sales. In response to accusations by consumer groups over unfair labor practices, Nike has developed a Corporate Responsibility Policy that discusses how to improve working. The policy of Nike includes, but is not limited to, the following initiatives: raising age limits in factories to 18 years, securing independent monitoring for the factories, extending a commitment to the environment, improving safety and health conditions, and providing educational programs (Nike, 1999). Nike in 2008, released its Trash Talk, the brand's first-ever basketball sneaker made entirely from manufacturing waste (Pelikan, 2012).

\section{Research Methodology}

\subsection{Case Study Approach}

The case study method is employed, since its fundamental characteristic is the "focus on a 
particular setting or event” (Stake, 1995).

\subsubsection{Sampling Method}

Purposeful sampling is the most appropriate for the case study approach, because 'information-rich' cases can be selected so as to get more information (Patton, 1990). Two types of purposeful sampling were used in combination: "snowball sampling" and "maximum variation sampling" (Minichiello et al., 1990). Snowball sampling relies on people identifying others to investigate. The maximum variation sampling was needed because it allows to pick cases purposefully and illustrate a wide range of variation on dimensions of interest. Thus, the interviewees came from different departments of the company. The General Manager was approached and he was asked to suggest five more people in the company from different departments. In particular, five in-depth interviews were conducted with the General Manager and top executives dealing with production, marketing, sales and public relations.

\subsubsection{Data Collection Methods}

Apart from the five in-depth interviews secondary data concerning general information about the company were gathered through press articles and the company's leaflets. In-depth interviews are considered to be the most valuable data collection method (Lincoln \& Guba, 1985). The in-depth interviews were based on a questionnaire with broad questions so as to allow respondents as much freedom in their answers as possible. The summation of the responses was based on the content analysis method (Stake, 1995). Qualitative content analysis was applied and the material from the interviews was divided into content analytical units. Thus, the results were carefully put into categories according to the points of interest of this study and the strong points were presented.

\section{The Findings}

\subsection{General Information}

As mentioned, Leon Tamaris \& Co is a Greek company producing women's footwear since 2000. In the beginning the company was only importing shoes and was the Greek representative of German firms.

The company is based in Athens and has representatives in the rest of Greece. The company had its premises at the industrial district of Taurus near the center of Athens. It had an office and a small production unit. In 2005, the company started to produce some of its products in Germany and the rest of the production remained in Greece.

It is a family business and its legal entity gives the company the possibility to get loans from the banks easily since its legal representative's personal assets can be used as a guarantee.

The company has a stable market share, despite the strong competition. The company's competitive advantage is the high quality of its products. It has s good fame in the market about its good quality of its products and their durability.

The company is aiming to increase its market share, as well as the increase of its sales and the decrease of its production costs 
Apart from its production, the company also imports every year twelve different series of products made from different materials. Most of this footwear is manufactured in Eastern Asia with low cost materials and low quality. Most of the shoes sold in the Greek market are not made in Greece.

\subsection{The Market}

The company's target market is women between the ages of 18 and 50. The market size and the market share of the company and its competitors are estimated on the basis of information gathered by its salesmen. In 2012, the company sold about 400.000 of pairs in the Greek market. A part of these are manufactured in Greece and another part in Germany, however, the major part is imported from China.

The company has a stable market share. However, customers due to the economic crisis are conservative in buying. The prices of low cost footwear have been influenced by the crisis since the buying power of consumers has decreased and this has affected the company's turnover.

In addition, the market size is expected to decrease, because of the decrease in births However, this will not significantly affect the sales of footwear, because today parents give more care and buy more goods, clothing and footwear for their children even for the grown ups who are unemployed and have not yet left the nest and working women pay more attention to their appearance and buy more shoes and clothes.

The company is mainly targeting the Greek and the Cypriot markets, however a part of the production is exported to European and Arab countries. The biggest Greek cities Athens and Thessalonica absorb the major part of the production.

Leon Tamaris \& Co communicates with its customers and tries to be aware of their needs. The company conducts market researches to identify customers' needs and assess their satisfaction. These market researches showed that customers are very satisfied with the company and the quality of its products.

\subsection{Competition}

Leon Tamaris \& Co is fighting competition by offering "value for money" and it has an intense promotion in fashion magazines. However, in Greece it is easy for a new competitor to enter the market by importing footwear from Eastern Asia and other countries. Everyone can visit the two exhibitions that take place in Europe and import quantities of footwear without having any special knowledge on these products. In Greece there are many companies in the footwear market and competition is severe. The major competitors are GEOX, CLARKS, TIMBERLAND and BOXER.

GEOX was established in 2000 and it is a well known brand worldwide. Due to its close contacts with designers, producers and retailers worldwide, the company offers a great variety of products designed by the most famous designers. In addition, it has exclusive collections and follows 'green' policies to protect the environment. The company has presence in more than 100 cities worldwide and has offices in the US, Europe, Japan. China, 
Hong Kong. The company offers excellent customer service including in-time delivery and reliability,

CLARKS was established in 1825, in Somerset Village in the US, when Cyrus Clark started to make carpets from sheepskin. In 1830, he and his brother started to make slippers from sheepskin wool and in 1856 in their production process the first 'Singer' sewing machines were introduced. Then, William Clark focused on giving special attention on the health of the feet and this was the beginning of the company's fame, as a producer of shoes healthy for the feet. In the 70's the company introduced polyurethane as a material for the shoe soles and gave extra comfort to its customers. Clarks was very successful in the UK and in the US and today it is the first brand in the world.

TIMBERLAND, introduced the technology of shoes without stitches that are completely waterproof. The shoes were distributed worldwide starting from Italy. Then the company opened a shop in Rhode Island. Gradually Timberland produced also women's shoes as well as clothes and accessories. The company produced the Timberland Grip Trail shoe sole, the first sole made from caoutchouc. In addition, the company produced the line 'Mukluk' targeting the VIP's. Timberland supported an Eco friendly policy and introduced the Active Technology (ACT) system in its shoes and clothes, which offered comfort and was taking into consideration climate changes.

BOXER was established in the city of Kalamata in Greece in 1919. The company, after its catastrophe in the Second World War moved to Athens and built a new factory there. In 1974 the company built a second factory and started to produce 5.000 pairs of shoes per day. The company became the biggest production unit in the sector and exported shoes to Germany to Russia and the UK. In 2006, BOXER was financed by the European Investment Programs of the Greek Ministry of Development and built a third factory with the latest technologies in the production process. Thus in 2010, the company expanded its production to 8.500 pairs per day and started exports in many more markets abroad.

\subsection{Analysis of the External Environment}

PEST is a tool for the analysis of the external macro-environment that affects all companies. P.E.S.T. is an acronym for the Political, Economic, Social, and Technological factors of the external macro-environment of a company or an organization. Such external factors usually are beyond the firm's control and sometimes present themselves as threats, however, some other times can create new opportunities (Kotler, 1994).

The external environment influences the company's operation and its success or failure. In addition it influences customers' attitude.

\section{Political Environment}

In Greece there are laws protecting companies from illegal rivalry and consumers and employees. There are also regulations and procedures for importing and exporting goods. In the sector of footwear, it is crucial for a company to monitor the legal framework which prescribes the production and distribution of footwear. Leon Tamaris \& Co is influenced by 
the political environment because it is importing from Germany and today due to the political contradiction between the two countries consumers do not prefer to buy products imported from Germany and they may shift to the competitors' products.

\section{Economic Environment}

Greece does not seem to recover from the economic crisis and today people who can be considered at the border of poverty have reached the $30 \%$, that is, about 1000.000 families. Unemployment has reached the highest levels especially for young people between 20 and 30 years old. Due to the crisis, footwear retailers reduced demand because their sales decreased significantly and the company in order to retain its economic heath had to decrease the salaries.

\section{Social Environment}

The majority of Leon Tamaris \& Co customers come from the middle class, thus the company is taking into consideration the changes that occur in the middle class such as the quality of living, their profiles, the aging of the population etc. The middle class has been significantly influenced by the economic crisis.

\section{Technological Environment}

In the footwear industry there are a lot of technological innovations in the production process and the materials that make shoes comfortable, waterproof etc. Thus, the company should have modern technological equipment in its production process. In addition, it should have the necessary infrastructure to achieve modern designs for its products.

\subsection{SWOT Analysis}

SWOT analysis is a tool for auditing an organization and its environment that helps marketers to focus on key issues. SWOT stands for strengths, weaknesses, opportunities, and threats and requires listing and analyzing these four issues (Doyle 1994). Thus, a SWOT analysis is performed to identify the company's strengths and weaknesses as well as its business opportunities and possible threats:

\section{Strengths}

The company is small and flexible, thus, it is easy to take decisions and make changes in the design of the products but also in other issues such as pricing, distribution and promotion. The whole chain of the process from the design stage up to the distribution is under the control of the company Companies that import their products cannot make changes since the products are designed by other companies abroad. The company has a good fame in the Greek market for the high quality of its products. It is experienced in the production of shoes since 2000 and has a good knowledge of the Greek market and it can easily adapt to the market needs.

\section{Weaknesses}

A weakness is the high prices of the products, since the company is selling its products at 


\section{Macrothink}

about $10 \%$ higher than the mean prices in the Greek market. Though, the brand name of the company can justify higher prices. The company's high prices are due to the superior quality of the materials and the production costs. However, in Greece there is a continuous decrease in the prices of footwear, due to the economic recession, for example hyperstores sell at very low prices, though the quality is not good. High prices is a serious disadvantage for the Greeks whose buying power has decreased.

\section{Opportunities}

Greeks show a significant interest for clothing and footwear and their spending on these is continuously increasing. Thus, the market increases and despite the economic crisis, the market share of the company remains stable and is expecting to increase its sales.

\section{Threats}

Mass imports from China of footwear in low prices which can not be competed. The quality is not good, however because prices are very low consumers buy these products and they are sold in big quantities.

In addition, recently two more competitors have entered the market. Although this is an indication of the potential of the market, these new competitors have taken market share.

In Table 1, SWOT analysis is presented.

Table 1: SWOT analysis

\begin{tabular}{|c|c|}
\hline \begin{tabular}{|l|} 
\\
Strengths \\
$\Rightarrow$ High product quality and good fame \\
$\Rightarrow$ Good knowledge of the Greek market \\
$\Rightarrow$ Flexibility \\
$\Rightarrow$ Total control from the design stage up to the \\
distribution
\end{tabular} & $\begin{array}{l}\text { Weaknesses } \\
\Rightarrow \text { High prices }\end{array}$ \\
\hline $\begin{array}{l}\text { Opportunities } \\
\Rightarrow \text { Greeks increasing spending on clothing and } \\
\text { footwear }\end{array}$ & $\begin{array}{l}\text { Threats } \\
\Rightarrow \text { Mass imports from China of footwear in low } \\
\text { prices } \\
\Rightarrow \text { New competitors }\end{array}$ \\
\hline$O$ & $T$ \\
\hline
\end{tabular}




\subsection{The Marketing Mix}

The marketing mix is also known as the 'four Ps', which are product, price, place and promotion. A fifth 'p' was also added to the marketing mix elements, people (Kotler 1994).

\section{Product}

The company produces footwear for women whose ages are between 18 and 50 years. The company designs and manufactures twelve different lines of products each year and each line has three or four types of shoes. Every line has its own name and is manufactured with the same materials.

The design of the products is unique for each line and changes every year according to fashion. The materials, the colors and especially the fabrics that are used are different for each line and they also change each year.

The company has innovative designs for its shoes. These designs are bought from specialized footwear designers abroad. After negotiating the cost the company signs a different agreement each time. Leon Tamaris \& Co has not bought the rights from any of these specialized footwear designers. Though, its competitors have bought such rights.

The company designs its products on the basis of customers' preferences and comfort and tries to select the suitable materials.

The products are manufactured on the basis of two criteria quality and price. The quality of the company's products is superior to the quality of its competitor's products. It is very difficult to decrease prices because quality should not be affected, thus every effort for price decrease should be made very carefully.

The products are packaged in plastic bags and in boxes, packaging, due to the nature of the product, cannot make the product more attractive.

The company is offering a two years guarantee for its products. It is also offering after sales service to its customers including information though the phone, repair and substitution of defective products. In the case that a product is damaged and can be repaired it is send to the company's small workshop for repair.

\section{Price}

Prices are defined on the basis of the cost of the designs, the models, the lines and the quantities that will be produced, the materials that will be used and the labor costs. Prices start from $30 €$ and arrive up to $150 €$ with a mean price between 80 and $100 €$.

In the Greek market women shoes' prices start from $30 €$ and arrive up to $150 €$ with a mean price between 60 and $80 €$. Thus, the company's prices are sometimes higher.

According to the results of the market researches, Greek consumers have a certain amount which they want to spend for shoes and this amount is between 60 and $100 €$ and they do not want to exceed this amount. In addition, price is a very important criterion for consumers when they buy footwear and influences their decision and if price is high they do not buy. 


\section{Macrothink

The company tries to keep prices within these limits.

The company also takes into consideration the prices of its competitors. Prices for its "Casual" shoes' range between 20 and $30 €$ and competitors' prices are about the same.

The company offers high quality footwear in good prices, thus it is considered as offering "value for money".

The policy of Leon Tamaris \& Co is not to make price reductions, but in some big retail stores the company offers a $5 \%$ reduction. In addition, if customers pay cash they also have a $5 \%$ reduction.

\section{Place}

The company sells its products directly to the retailers. Thus, the company's products are distributed to big footwear retail stores, small regional stores and big stores in the shopping malls. The company is adapting its distribution channel to the market needs. The company has two experienced salesmen and uses courier companies for the delivery of its products. In addition, it has sales representatives all over Greece. Sales representatives are paid with a commission on their sales.

In the previous years, quality shoes were sold only in big stores at the center of the cities, however, now consumers can find shoes of good quality also in smaller regional stores. In addition, the opening of shopping malls and the big chains selling clothing and footwear have changed the market since a significant number of consumers buy footwear there.

Furthermore, it should be mentioned that many small local retail stores can not compete in prices with the big chains and they close down. This problem is more intense outside Athens

Leon Tamaris' products are of high quality, thus the company will not sell its products through super markets and hyperstores. This would destroy the company's image, though some of its competitors sell also through this channel

The company is always trying to satisfy retailers, who want fast delivery, reliability and flexibility. Thus, the company is making efforts to minimize the waiting time for the delivery.

\section{Promotion}

Leon Tamaris \& Co is collaborating with an advertising agency which organizes its promotional activities.

The company places advertisements in fashion magazines and until 2002 promotion was done also through the television. The company distributes promotional material such as leaflets to the retail stores which are given to customers and posters which are placed on the retail stores' windows. Each year this promotional material is renewed. The company also offers a $20 \%$ discount to customers on their next purchase.

The company has an excellent phone service for customers. Its salesmen and its sales representatives can effectively communicate with customers and do well in public relations. 


\section{Macrothink}

\section{People}

The company has 20 employees, 12 employees in the production and 8 in the administration. Since is it small the company prefers to have external collaborators the permanent staff. Thus, the company uses one external collaborator for distribution and another one to observe market trends who is also a footwear designer. In addition the company has an accountant and an assistant accountant.

The company's employees are qualified, know the product well and they are well trained. The company is always trying to select the right employees to best fill all the positions.

\section{Discussion}

Greece was hit hard by the international recession and does not seem to recover soon. The majority of the customers of Leon Tamaris \& Co come from the middle class and they have been severely hurt by the economic crisis, thus their buying power has decreased.

In addition, the company is influenced by the political environment because it imports mainly from Germany and due to the political contradiction between the two countries consumers do not prefer to buy products imported from Germany.

The company is small it has 20 employees like most of the footwear companies in the EU which employ less than 20 people (CBI, 2010b), however this makes the company flexible and it is able to have the control of the whole chain of the process from the design stage up to the distribution.

Competition is strong because of the mass imports of footwear from China in very low prices. In addition, new competitors enter the market and the company is making strong efforts to beat competition.

Greeks show a significant interest for clothing and footwear and their spending on these is continuously increasing. Thus, despite the economic crisis and the strong competition, the company has very encouraging results, its market share remains stable and an increase in its sales is expected.

Its products are of higher quality than its competitors. The high quality of its products in comparison with prices has given the company a good fame in the market and it is considered a company offering 'value for money'.

The company sells its products about $10 \%$ higher than the mean prices in the market and this is due to the superior quality of the materials and the production cost, however, the brand name of the company can justify the higher prices.

In order to determine its prices the company takes into consideration the prices of its competitors (Mplans, 2012) and Greek customers' 'reference prices' for footwear, that is, the prices consumers expect or deem is reasonable for footwear.

The company has its own retail network as most companies in the sector of footwear have (CBI 2010b), controlling in this way the promotion of their products in the market However, 
the company does not sell its products through supermarkets and hyperstores, because this would destroy its brand image.

The company's promotional activities include advertising in fashion magazines which is a common marketing practice for many companies in this sector (Mplans, 2012) and the distribution of promotional material such as leaflets to the retail stores to be given to customers. In addition, it offers discounts to certain customers. Since its target market is women between the ages 18-50 the company could target its promotional activities to female consumers e.g. by sponsoring female events.

The company has modern technological equipment in its production process and as Pelikan (2012) mentioned the footwear industry worldwide is recognizing the importance to improve its production methods and use energy conserving machinery because in this way it can cut costs and go green

The company conducts market researches to identify customers' needs and assess their satisfaction with its products. These market researches revealed that customers are very satisfied with the company and the quality of its products. As Pelikan (2012) stated, conducting marketing research on a continual basis to gain a better understanding on what customers would like to see in the market has been a critical success factor for major players in the footwear market such as Nike.

The company's has well trained employees who know the product well. Providing training to employees is a prerequisite for companies' success in the sector of footwear and in all sectors (Nike, 1999).

\section{The Contribution of This Study}

This study contributes to the footwear sector since it is the only one so far that has provided an important insight in the production and marketing of footwear and has gathered knowledge concerning the Greek market where very limited research has taken place in this sector. The results of the study support the findings of other studies mentioned in the literature and they can be of definite interest and potential value to managers in this sector. Academically, further research based on these findings can add to the present pool of knowledge by further examining the marketing practices employed by other companies in Greece and worldwide.

\section{References}

CBI. (2010). The Footwear Market in the EU, CBI (Centre for the Promotion of Imports from developing countries) Market Survey. Retrieved June 03, 2012, fom http://www.reportlinker.com/ci02119/Footwear.html

CBI. (2010a). The Footwear Market in the EU', CBI (Centre for the Promotion of Imports from developing countries) Market Survey. Retrieved June 03, 2012, fom http://www.reportlinker.com/ci02119/Footwear.html

CBI. (2010b). The Footwear Market in Greece and Cyprus, CBI (Centre for the Promotion of 


\section{Macrothink}

Imports from developing countries), Market Survey. Retrieved June 03, 2012, fom http://www.cbi.eu/marketinfo

Doyle, P. (1994). Marketing Management \& Strategy. New Jersey: Prentice Hall.

GIA. (2012). Global Footwear Market to Reach 15.7 Billion Pairs by 2017, GIA-Global Industry Analysts, Inc., March 21 2012, San Jose, CA (PRWEB). Retrieved June 08, 2012, fom

http://www.prweb.com/releases/footwear_casual_formal/athletic_outdoor_rugged/prweb9311 804.htm

Kathimerini. (2012). Decrease 12.4\% in the production of footwear'Newspaper Kathimerini.

Retrieved May 28, 2012, fom http://portal.kathimerini.gr/4dcgi/_w_articles_kathbreak_1_03/10/2011_409126

Kotler, P. (1994). Marketing Management - Analysis, Planning, Implementation and Control. New Jersey: Prentice Hall.

Lincoln, Y. S., \& Guba, E. G. (1985). Naturalistic Inquiry. Newbury Park: CA Sage.

Minichiello, V., Aroni, R., Timewell, E., \& Alexander, L. (1990). In-depth Interviewing: Researching People. Melbourne: Longman Creshire.

Mplans. (2012). Women's Shoe Store Marketing Plan, Mplans.com. Retrieved July 23, 2012, from

http://www.mplans.com/womens_shoe_store_marketing_plan/marketing_strategy_fc.php\#ixz z21j1uCSrT

Nike. (1999). Footwear Marketing, Strategic Analysis of Nike, Inc., Nike, Inc. 1999 Annual Report. Retrieved July 04, 2012, from http://footweardesigner.blogspot.gr/2007/10/strategic-analysis-of-nike.html

Patton, M. Q. (1990). Qualitative Evaluation and Research Method (2nd ed.). Newbury Park: CA Sage.

Pelikan, K. (2012). Shoe Industry Steps into Green Manufacturing. Retrieved July 26, 2012, from http://ezinearticles.com/?Shoe-Industry-Steps-Into-Green-Manufacturing\&id=3764163

Stake, R. (1995). The art of case study research. Newbury Park: CA Sage.

Vima. (2009). The sales of footwear, Newspaper Vima. Retrieved June 03, 2012, from http://www.tovima.gr/finance/finance-news/article/?aid=303851

\section{Copyright Disclaimer}

Copyright reserved by the author(s).

This article is an open-access article distributed under the terms and conditions of the Creative Commons Attribution license (http://creativecommons.org/licenses/by/3.0/). 